Syntax Literate: Jurnal Ilmiah Indonesia p-ISSN: 2541-0849

e-ISSN: 2548-1398

Vol. 6, No. 1, Januari 2021

\title{
OPTIMALISASI PERAN BALAI PEMASYARAKATAN DALAM PELAKSANAAN PEMBINAAN TERHADAP ANAK PELAKU TINDAK PIDANA YANG DIBEBASKAN DIMASA PANDEMI COVID 19
}

\author{
Yohana Damayanti Br Kaban dan Beniharmoni Harefa \\ Universitas Pembangunan Nasional Veteran Jakarta \\ Email: yohanakaban02@gmail.com dan beniharefa@upnvj.ac.id
}

\section{Abstract}

During the Covid-19 pandemic, the government through the Ministry of Law and Human Rights reviewed the policy through Permenkumham No 10 in 2020 regarding the release of assimilation and the executive order making the child the perpetrator of this crime many were released. This makes bapas must improve the implementation of the development of the freed child. The problem in this study is how to optimize $B A P A S$ in the implementation of child development as the perpetrator of crimes that are released because of Covid-19 and the obstacles faced by bapas in the implementation of the construction. The purpose of this study is to know how to optimize BAPAS in the development of children as perpetrators of crimes that are released because of Covid-19 and know the obstacles faced by bapas in the implementation of the construction of children as perpetrators of the crime struck. The research method used is normative juridical using secondary data obtained through literature studies such as scientific books, journals, laws. From this research it can be concluded that due to the human resources that are not proportional to the number of child prisoners who are released so that the performance is not optimal, the Correctional Center works together and empowers the community in the environment where the child prisoners live concerned to ensure assimilation and integration. This makes it possible to ensure reintegration of children and increase children's confidence in their original communities and ensure their future.

Keywords: correctional center; child; covid-19

\section{Abstrak}

Dimasa pandemi Covid-19, pemerintah melalui Kementerian Hukum dan HAM mengeluarkan kebijakan melalui Permenkumham No. 10 tahun 2020 terkait pembebasan dan asimilasi membuat anak sebagai pelaku tindak pidana ini banyak yang dibebaskan. Hal tersebut membuat pihak Balai Pemasyarakatan harus meningkatkan pelaksanaan pembinaan terhadap anak yang dibebaskan tersebut. Permasalahan dalam penelitian ini adalah bagaimana optimalisasi Balai Pemasyarakatan dalam pelaksanaan pembinaan anak sebagai pelaku tindak pidana yang dibebaskan karena Covid-19 dan kendala yang dihadapi pihak Balai Pemasyarakatan dalam pelaksanaan pembinaan tersebut. Tujuan penelitian ini adalah mengetahui bagaimana optimalisasi Balai Pemasyarakatan dalam pelaksanaan pembinaan anak sebagai pelaku tindak pidana yang dibebaskan karena Covid-19 dan mengetahui kendala-kendala yang dihadapi pihak Balai Pemasyarakatan dalam 
pelaksanaan pembinaan terhadap anak sebagai pelaku tindak pidana yang dibebaskan tersebut. Metode penelitian yang digunakan adalah yuridis normatif dengan menggunakan data sekunder yang diperoleh melalui studi kepustakaan seperti bukubuku ilmiah, jurnal, undang-undang. Dari penelitian ini dapat ditarik kesimpulan bahwa dikarenakan sumder daya manusia yang tidak sebanding dengan jumlah narapidana anak yang dibebaskan sehingga membuat kinerja menjadi tidak maksimal maka dari pihak Balai Pemasyarakatan bekerja sama dan memberdayakan masyarakat di lingkungan tempat tinggal narapidana anak terkait untuk menjamin asimilasi dan integrasi yang dilakukan. Hal itu memungkinkan terjaminnya reintegrasi anak dan menambah kepercayaan diri anak ke dalam masyarakat asal serta menjamin masa depan mereka.

Kata kunci: balai pemasyarakatan; anak; covid-19

Coresponden Author

Email: yohanakaban02@gmail.com Artikel dengan akses terbuka dibawah lisensi

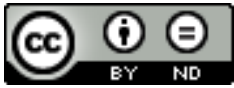

\section{Pendahuluan}

Anak-anak memang harus dijaga dengan baik, karena merekalah yang akan meneruskan masa depan bangsa Indonesia. Dalam Konstitusi Indonesia, anak memiliki peran strategis yang secara tegas dinyatakan bahwa negara menjamin hak setiap anak atas kelangsungan hidup, tumbuh, dan berkembang serta atas perlindungan dari kekerasan dan diskriminasi. Perlindungan hukum terhadap hak-hak anak bermaksud untuk melindungi berbagai kepentingan yang menyangkut dengan kesejahteraan anak bahkan masa depan anak. Salah satu bentuk perlindungan hukum bagi hak asasi anak, yaitu perlindungan hukum terhadap anak yang berada dalam sistem peradilan pidana anak.

Menurut data yang dilansir dari CNN Indonesia tahun 2020, masalah anak yang berkonflik dengan hukum mempunyai kecenderungan semakin meningkat. Catatan kriminalitas terkait anak di Indonesia seperti yang diungkapkan oleh Direktur Bimbingan Kemasyarakatan dan Pengentasan Anak Ditjen Pemasyarakatan, menunjukkan data bahwa anak-anak yang berada di lingkungan Rutan Tahanan Negara (Rutan) dan Layanan Pemasyarakatan berjumlah 3.812 orang. Anak-anak yang diversi sebanyak 5.229 orang, dan total sekitar 10 ribu anak termasuk mereka yang sedang menjalani asimilasi, pembebasan bersyarat dan cuti jelang bebas.

Balai Pemasyarakatan adalah salah satu pihak yang terlibat selama proses peradilan anak yang berkonflik dengan hukum dari awal anak ditangkap hingga anak menyelesaikan masa hukumannya. Misi atau tugas mulia yang diemban Balai Pemasyarakatan tersebut belum dapat berjalan dengan optimal, disebabkan oleh beberapa faktor. Salah satu faktor yang menghambat pelaksanaan pelayanan dan pembinaan pemasyarakatan yaitu wilayah kerja Balai Pemasyarakatan yang terlampau luas dan letak geografis. Sementara, jumlah sumber daya manusia Pembimbing Kemasyarakatan (PK), sarana dan prasarana serta daya dukung operasional lainnya sangat minim jika dibandingkan dengan jumlah warga binaan pemasyarakatan (WBP) yang harus dilayani. 
Jumlah Unit Pelaksana Teknis (UPT) Balai Pemasyarakatan yang ada ternyata masih jauh dari ideal. Sebagai perbandingan, saat ini Balai Pemasyarakatan di seluruh Indonesia berjumlah 71 UPT dengan klasifikasi I berjumlah 17 satuan kerja dan klasifikasi II berjumlah 54 satuan kerja, sedangkan jumlah Kabupaten/Kota saat ini berjumlah 539, yang terdiri atas 34 provinsi, 412 kabupaten, dan 93 kota (tidak termasuk 5 (lima) kota administratif dan 1 (satu) kabupaten administratif di Provinsi DKI Jakarta) (Trisapto, 2020)

Dimasa pandemi Covid-19 ini pemerintah mengeluarkan kebijakan Permenkumham No. 10 tahun 2020 tentang Asimilasi dan Integrasi sehingga pihak Balai Pemasyarakatan membebaskan anak bimbingannya demi mencegah penyebaran Covid19. Dilansir dari berita CNN Kementerian Hukum dan Hak Asasi Manusia (Kemenkumham) membebaskan 13.430 narapidana dan anak melalui program asimilasi dan integrasi. Langkah itu sebagai upaya mengantisipasi penyebaran Covid-19 di Lembaga Pemasyarakatan dan Rumah Tahanan yang kapasitasnya meledak. Anak-anak yang dibebaskan tersebut tetap diawasi oleh pihak Balai Pemasyarakatan hanya dengan sistem daring seperti melakukan videoconference atau sejenisnya. Pengawasan dan pembinaan dilakukan secara berkala selama waktu yang sudah ditentukan sebelumnya. Kemudian, para petugas akan mencatat dan mengirim laporan segala perkembangan mereka.

Hal ini menjadi koreksi penting pihak Balai Pemasyarakatan karena jumlah sumber daya yang tidak sebanding dengan jumlah narapidana yang dibebaskan karena covid-19. Permasalahan yang diangkat oleh penulis adalah bagaimana optimalisasi dari Balai Pemasyarakatan dalam pelaksaan pembinaan terhadap anak sebagai pelaku tindak pidana yang dibebaskan dimasa Covid-19 dan kendala-kendala apa saja yang dihadapi Balai Pemasyarakatan dalam pelaksanaan pembinaan terhadap anak sebagai pelaku tindak pidana yang dibebaskan dimasa Covid-19. Pada penelitian terdahulu yang berjudul Peran Balai Pemasyarakatan Pada Sistem Peradilan Pidana Anak Di Tinjau Dalam Perspektif Hak Asasi Manusia (Okky, 2017) dengan hasil peran Balai Pemasyarakatan belum maksimal dalam penanganan pembimbingan dan pendampingan narapidana anak. Sedangkan dalam penelitian ini memfokuskasn untuk mengetahui optimalilasi peran Balai Pemasyarakatan dalam pembebasan narapidana anak dimasa Covid-19. Pentingnya penelitian ini supaya mengetahui langkah atau strategi yang harus dilakukan pihak Balai Pemasyarakatan terkait kebijakan asilasi dan integrasi demi masa depan anak yang lebih baik.

Penulis mengangkat penelitian ini bertujuan untuk mengetahui peran Balai Pemasyarakatan dalam peningkatan pembinaan terhadap anak sebagai pelaku tindak pidana yang dibebaskan dimasa Covid-19 dan mengetahui kendala-kendala apa saja yang dihadapi pihak Balai Pemasyarakatan dalam pelaksanaan pembinaan dimasa Covid-19 terhadap anak sebagai pelaku tindak pidana yang dibebaskan tersebut. 
Optimalisasi Peran Balai Pemasyarakatan dalam Pelaksanaan Pembinaan terhadap Anak Pelaku Tindak Pidana yang dibebaskan dimasa Pandemi Covid 19

\section{Metode Penelitian}

Metode yang digunakan dalam penelitian ini yakni metode penelitian yuridis normatif. Metode penelitian hukum ini berfungsi untuk melihat hukum dalam artian nyata dan meneliti bagaimana bekerjanya hukum di lingkungan masyarakat. Data sekunder sebagai bahan dasar dalam penelitian ini, dapat berupa berbagai bahan hukum, baik bahan hukum primer maupun bahan hukum sekunder. Bahan hukum primer terdiri dari perundang-undangan khususnya perundangan-undangan terkait perlindungan anak dan sistem peradilan pidana anak. Bahan hukum sekunder terdiri dari buku-buku teks, jurnaljurnal hukum, khususnya buku dan jurnal terkait sistem pelaksanaan pembinaan BAPAS dan terkait Covid-19. Teknik pengumpulan data berupa studi pustaka, observasi dan dokumentasi.

\section{Hasil dan Pembahasan}

Dalam konteks pandemi Covid-19 di lingkungan lembaga pemasyarakatan, Scott (2020) fokus melihat bagaimana lingkungan lembaga pemasyarakatan terpengaruh oleh pandemi Covid-19 dan seberapa tinggi risiko penularan virus berlangsung. Scott melihat bila pada dasarnya, kondisi lembaga pemasyarakatan di seluruh dunia yang kebanyakan mengalami persoalan seperti kepadatan populasi tahanan yang tinggi, sirkulasi udara yang buruk, serta standar sanitasi dan makanan yang rendah, menjadikan lembaga pemasyarakatan sebagai tempat terburuk sepanjang pandemi berlangsung, menjadikan narapidana secara keseluruhan menghadapi risiko kesehatan yang sangat besar. Melihat dari perspektif antropologi, Scott menilai penting bagi pemangku kebijakan untuk menerapkan kebijakan yang didasarkan pada inklusi sosial, rehabilitasi berbasis komunitas, serta berasaskan kebebasan bergerak (freedom of movement) (Scott, 2020).

Masih dalam bahasan serupa, Simpson \& Butler (2020) dan Barnert et al. (2020) turut melihat risiko besar penyebaran virus di dalam fasilitas lembaga pemasyarakatan selama berlangsungnya pandemi Covid-19. Simpson \& Butler menggarisbawahi bila lembaga pemasyarakatan telah lama diakui sebagai ruang inkubator bagi penyakit menular, di mana telah terjadi berbagai kasus sebelum Covid-19 di mana pelepasan tahanan justru mengakibatkan dampak negatif bagi masyarakat sekitar. Kasus tifus di Inggris abad ke-16 dan amnesti di Rusia pada 1997 dan 2001 yang ditujukan untuk mengurangi dampak dan penyebaran tuberkulosis di penjara-penjara yang terlalu padat, di mana kedua kasus tersebut justru berakibat tersebarnya penyakit menular terkait ke masyarakat (Simpson \& Butler, 2020). Barnert et al. melihat bila kondisi lembaga pemasyarakatan yang sering kali terlalu padat, ventilasi dan sanitasi yang buruk, serta standar kebersihan yang rendah, berujung pada tingginya risiko Covid-19 (Elizabeth Barnert, Ahalt, \& Williams, 2020). Kedua artikel merekomendasikan pentingnya untuk mengurangi populasi penjara melalui pembebasan tahanan yang didasarkan pada analisa risiko dari individu terkait terhadap komunitas serta ancaman terhadap Covid-19.

Hal yang sama turut dibahas oleh Sulhin (2020), di mana ia fokus membahas persoalan yang ada dalam lembaga pemasyarakatan di lingkup Indonesia. Sebelum pandemi berlangsung, seluruh lembaga pemasyarakatan di Indonesia telah mengalami 
persoalan besar terkait overcrowding dan pemenuhan hak minimum bagi tahanan dan narapidana. Lebih spesifik dalam konteks kesehatan, saranan dan prasarana layanan kesehatan, termasuk ketersediaan obat-obatan dan tenaga kesehatan, sering kali tidak mencapai standar yang telah ditentukan dalam UU No. 12 tahun 1995. Dengan adanya fenomena pemenjaraan berlebihan yang berlangsung di Indonesia, penting untuk kemudian adanya penerapan kebijakan yang lebih manusiawi dan realistis dengan fakta overcrowding di penjara, termasuk kebijakan seperti pembebasan serta penerapan community-based corrections sedari awal (Sulhin, 2020).

Dalam bahasan dampak pandemi Covid-19 terhadap narapidana anak, Bateman (2020) melihat bila narapidana anak telah mengalami pembatasan kebebasan yang sangat besar di dalam lembaga pemasyarakatan. Dengan penerapan berbagai kebijakan seperti isolasi tahanan, narapidana anak kemudian harus menjalani kehidupan sehari-hari dengan sedikit atau tanpa kontak sosial. Lebih lanjut, isolasi yang berlangsung turut dibarengi dengan pemberhentian total kunjungan personal ataupun profesional, berakibat pada total ketiadaan kontak sosial yang dilakukan oleh tiap narapidana anak. Dengan perlakuan terhadap narapidana anak sepanjang Covid-19 yang dianggap tidak manusiawi, Bateman menilai bila penting untuk menerapkan kebijakan yang lebih manusiawi, seperti pembebasan narapidana anak ke tempat tinggal mereka masing-masing (Bateman, 2020).

Serupa dengan bahasan Bateman, Buchanan et al. (2020) secara fokus membahas dampak dari Covid-19 terhadap narapidana anak yang ada dalam sistem peradilan. Serupa dengan berbagai bahasan di atas, Buchanan et al. menemukan bila Covid-19 secara fundamental memberikan tantangan bagi tiap lembaga pemasyarakatan, menekankan pentingnya upaya untuk mengurangi populasi tahanan dalam penjara. Walau demikian, Buchanan et al. turut menyadari bila upaya untuk mendesain sistem yang sesuai dengan panduan kesehatan dan kebijakan social-distancing dalam tiap lembaga pemasyarakatan akan sulit untuk dilakukan, mengingat banyak dari lembaga pemasyarakatan yang mengalami keterbatasan sumber daya, baik modal ataupun manusia (Buchanan, Castro, Kushner, \& Krohn, 2020). Lebih lanjut dalam bahasan tersebut, Barnert (2020) menemukan bila selain berbagai permasalahan yang ada dalam tiap lembaga pemasyarakatan seperti yang telah dibahas oleh berbagai tulisan di atas, hal-hal seperti persoalan emosional, kekerasan seksual, dan tekanan-tekanan lainnya yang berlangsung dalam penjara memberikan tiap tahanan, terutama narapidana anak, tekanan tambahan yang dianggap memperlemah sistem imun mereka, memperburuk kemungkinan transmisi Covid-19 (Elizabeth S. Barnert, 2020).

Masuk ke dalam konteks kebijakan Asimilasi dan Integrasi yang diterapkan oleh Kemenkumham, terdapat berbagai tulisan yang secara spesifik membahas implementasi dan dampak dari kebijakan tersebut, masing-masing dari berbagai perspektif dan fokus yang berbeda. Trisnawati (2020) dalam tulisannya memberikan pembahasan terkait overview kebijakan asimilasi dan integrasi narapidana dan anak. Di luar urgensi dan alasan mengenai penerapan kebijakan ini, Trisnawati menemukan bila terdapat tiga hambatan utama dalam penerapan kebijakan asimilasi dan integrasi terkait Covid-19. Ketiga hambatan tersebut antara lain adalah adanya ketidakjelasan alamat tujuan warga 
binaan lembaga pemasyarakatan, adanya pemanfaatan kebijakan oleh narapidana yang dibebaskan demi kepentingan pribadi, serta keraguan dari masyarakat luas untuk menerima kedatangan narapidana dan anak yang dibebaskan (Trisnawati, 2020).

Jufri \& Anisariza (2017) melakukan pembahasan atas asimilasi narapidana yang dilakukan oleh lembaga pemasyarakatan Terbuka Jakarta sebelum pandemi Covid-19. Sebagai salah satu kebijakan untuk mengurangi overcrowding di fasilitas lembaga pemasyarakatan, kebijakan asimilasi dianggap memberikan baik dampak positif dan negatif. Dampak positif yang terlihat jelas dapat dilihat dari sisi narapidana, di mana kebijakan asimilasi memberikan narapidana kesempatan untuk membaur dengan publik serta menjadi sumber pendapatan selama mereka menjalani masa hukuman. Di sisi lain, kebijakan ini dianggap mengalami berbagai kendala, di mana keterbatasan sumber daya yang dimiliki oleh lembaga pemasyarakatan mengartikan SDM yang ada harus bekerja lebih ekstra, serta sulit untuk menemukan mitra ketiga bagi proses asimilasi narapidana (Jufri \& Anisariza, 2017).

Lebih lanjut dalam konteks Covid-19, Tirtakusuma (2020), Rizky (2020), Appludnopsanji \& Disemadi (2020), serta Khoirunnisa (2020) memberikan pembahasan atas dampak serta persoalan terkait penerapan kebijakan asimilasi dan pembebasan narapidana. Tirtakusuma (2020) menggarisbawahi pembahasan pada bagaimana kemudian kebijakan asimilasi dan pembebasan narapidana memodifikasi hukuman yang telah diputuskan oleh sistem peradilan. Dengan pengkajian kebijakan asimilasi melalui aspek yuridis, filosofis, dan sosiologis, Tirtakusuma menilai bila kebijakan asimilasi, setidaknya melalui perspektif aspek filosofis, tetap sesuai dengan tujuan dasar proses pemidanaan. Kebijakan asimilasi dinilai Tirtakusuma mampu mengurangi kemungkinan overpunishment, di mana narapidana harus menjalani hukuman penuh bersamaan dengan tekanan psikologis yang ditimbulkan oleh risiko pandemi Covid-19 (Tirtakusuma, 2020).

Rizky (2020) melakukan pembahasan terkait dampak positif yang diberikan oleh kebijakan asimilasi dan integrasi bagi narapidana semasa pandemi Covid-19. Rizky secara garis besar menemukan dua dampak positif utama dari penerapan kebijakan ini terutama terkait dengan fenomena overcrowded di fasilitas lembaga pemasyarakatan, yaitu penghematan anggaran negara serta peningkatan produktivitas narapidana di dalam lembaga pemasyarakatan. Perihal penghematan anggaran negara, kalkulasi anggaran yang dilakukan berdasarkan laporan rerata biaya hidup narapidana per hari menunjukkan penghematan anggaran negara sebesar lebih dari Rp340 miliar, di mana anggaran tersebut dapat kemudian dialokasikan pada upaya penyediaan sarana dan prasarana kesehatan di dalam tiap fasilitas lembaga pemasyarakatan. Perihal produktivitas, pembatasan aktivitas di tiap lembaga pemasyarakatan mengartikan adanya waktu lebih bagi narapidana untuk bekerja di UPT permasyarakatan yang memiliki industri produktif sendiri (Rizky, 2020).

Appludnopsanji \& Disemadi (2020) memberikan bahasan terkait permasalahan yang muncul dari kebijakan asimilasi dan integrasi narapidana. Secara sederhana, permasalahan yang berpotensi timbul banyak terkait pada hubungan antar narapidana di dalam lembaga pemasyarakatan. Dengan adanya persyaratan pembebasan bersyarat yang diatur, Appludnopsanji \& Disemadi menilai bila akan timbul kecemburuan narapidana 
yang tidak memeroleh kesempatan untuk bebas, berujung pada peningkatan kriminalitas dalam lingkungan lembaga pemasyarakatan. Lebih lanjut, narapidana yang dibebaskan turut dikhawatirkan akan melalukan tindak kejahatan, menghilangkan esensi dari upaya pengintegrasian narapidana ke dalam masyarakat (Appludnopsanji \& Disemadi, 2020). Dalam pembahasan serupa, Khoirunnisa (2020) menemukan bila terdapat kemungkinan bila narapidana yang dibebaskan kemudian akan menjadi polemik baru di masyarakat, di mana terdapat kesulitan bagi tiap lembaga pemasyarakatan untuk menjamin seluruh narapidana yang dibebaskan bersyarat melalui kebijakan ini akan berkelakuan baik setelah dibebaskan dan diintegrasikan kembali ke dalam masyarakat (Khoirunnisa, 2020).

Dalam konteks program asimilasi dan integrasi masa Covid-19 bagi narapidana anak, Umronah (2020) dan Saimima \& Noviansyah (2020) masing-masing memberikan analisis terkait proses pelaksanaan kebijakan asimilasi dan integrasi narapidana anak di masa Covid-19. Umronah (2020) dalam tulisannya membahas bagaimana proses pengawasan asimilasi dan integrasi bagi narapidana dan anak berlangsung. Dalam proses tersebut, Umronah melihat bila terdapat berbagai faktor yang kemudian mempengaruhi pengawasan kebijakan ini, mulai dari ketersediaan klien (baik jumlah petugas ataupun kesiapan menjalani pengawasan, keterbatasan SDM, pemanfaatan teknologi dan informasi, serta pengelolaan administrasi terutama terkait penyebaran Covid-19 di luar lingkungan lembaga pemasyarakatan (Umronah, 2020). Saimima \& Noviansyah (2020) dalam tulisannya memberikan model untuk memberdayakan dan melibatkan masyarakat di lingkungan tempat tinggal narapidana anak terkait untuk menjamin asimilasi dan integrasi yang dilakukan. Selain untuk menjamin keberhasilan proses reintegrasi narapidana anak ke dalam masyarakat, model ini ditujukan untuk dapat membangun kepercayaan diri narapidana anak, menjamin perolehan pendidikan, membangun dan mendorong perubahan diri, sikap serta kedisiplinan anak, serta membangun jiwa pengabdian pada negara (Saimima \& Noviansyah, 2020). Inovasi dalam penelitian ini adalah dapat memberi kebijakan yang lebih baik terkait asimilasi dan integrasi pada narapidana anak pada masa Covid-19 ini demi masa depan anak yang berkualitas.

\section{Kesimpulan}

Berdasarkan pembahasan yang dilakukan di atas, pada dasarnya terlihat apabila fasilitas lembaga pemasyarakatan, baik di level global ataupun di Indonesia, sama-sama mengalami persoalan seperti overcrowded dan keterbatasan sumber daya, yang mana permasalahan ini memberikan tantangan bagi pencegahan transmisi virus Covid-19 dalam lingkungan lembaga pemasyarakatan. Dalam konteks kebijakan asimilasi dan integrasi narapidana dan anak yang diambil oleh Kemenkumham sebagai upaya kontrol dan penanggulangan transmisi Covid-19 dalam lingkungan lembaga pemasyarakatan, dapat dikatakan bila kebijakan ini memiliki dampak, baik positif dan negatif. Fokus pada bahasan narapidana anak, kebijakan ini memungkinkan terjaminnya reintegrasi anak ke dalam masyarakat asal serta menjamin masa depan mereka, seperti akses pada pendidikan melalui berbagai layanan sosial yang ada. Walau demikian, terdapat keterbatasan dalam menemukan bahasan yang secara spesifik melihat kendala teknis yang dialami oleh 
Optimalisasi Peran Balai Pemasyarakatan dalam Pelaksanaan Pembinaan terhadap Anak Pelaku Tindak Pidana yang dibebaskan dimasa Pandemi Covid 19

lembaga pemasyarakatan dalam pelaksanaan kebijakan ini, selain temuan seperti keterbatasan sumber daya modal dan manusia. 


\section{BIBLIOGRAFI}

Appludnopsanji, \& Disemadi, Hari Sutra. (2020). Problematika Kebijakan Pembebasan Narapidana sebagai Upaya Penanggulangan COVID-19 di Indonesia. Wawasan Yuridika, 4(2), 131-148. https://doi.org/10.25072/jwy.v4i2.369

Barnert, Elizabeth, Ahalt, Cyrus, \& Williams, Brie. (2020). Prisons: Amplifier of the COVID-19 Pandemic Hiding in Plain Sight. American Journal of Public Health, 110(7). https://doi.org/10.2105/AJPH.2020.305713

Barnert, Elizabeth S. (2020). COVID-19 and youth impacted by juvenile and adult criminal justice systems. Pediatrics Perspective, 146(2). https://doi.org/10.1542/peds.2020-1299

Bateman, Tim. (2020). Unjust pains: the impact of COVID-19 on children in prison. Journal of Children's Services, (September), 1-14. https://doi.org/10.1108/JCS-072020-0045

Buchanan, Molly, Castro, Erin D., Kushner, Mackenzie, \& Krohn, Marvin D. (2020). It's F**ing Chaos: COVID-19's Impact on Juvenile Delinquency and Juvenile Justice. American Journal of Criminal Justice, 45(4), 578-600. https://doi.org/10.1007/s12103-020-09549-x

Gadis Vitayanty Noor (2016). Optimalisasi peran Balai Pemasyarakatan dalam Sistem Peradilan Pidana Anak Berdasarkan Undang-undang No. 11 Tahun 2012 Studi Di Balai Pemasyarakatan Kelas II Pekalongan. Jurnal Diponegoro Law Review, Vol. 5 No. 2

Jufri, Ely Alawiyah, \& Anisariza, Nelly Ulfah. (2017). Pelaksanaan Asimilasi Narapidana di Lembaga Pemasyarakatan Terbuka Jakarta. ADIL: Jurnal Hukum, 1-26. https://doi.org/10.33476/ajl.v8i1.452

Khoirunnisa, Nurul Aulia. (2020). Dampak Pembebasan Narapidana pada Lingkungan Masyarakat di Tengah Wabah Virus COVID-19. Jurnal Dinamika Penelitian: Media Komunikasi Sosial Keagamaan, 20(1), 112-129.

Margie G. Sopacua (2015). Peran Balai Pemasyarakatan Dalam Proses Penyelesaian Tindak Pidana Yang Dilakukan Anak Berbasis Restoratif Justice. Jurnal Sasi, Vol. 21 No. 2

Okky Chahyo Nugroho (2017). Peran Balai Pemasyarakatan Pada Sistem Peradilan Pidana Anak Di Tinjau Dalam Perspektif Hak Asasi Manusia. Jurnal HAM, Vol. 8 No. 2

Rizky, Bayu. (2020). Dampak Positif Bagi Narapidana Dalam Pencegahan Dan Penaggulangan Covid-19. JUSTITIA : Jurnal Ilmu Hukum Dan Humaniora, 7(3), $655-665$. 
Optimalisasi Peran Balai Pemasyarakatan dalam Pelaksanaan Pembinaan terhadap Anak Pelaku Tindak Pidana yang dibebaskan dimasa Pandemi Covid 19

Saimima, Ika Dewi Sartika, \& Noviansyah. (2020). Model Persuasif Edukatif Bagi Masyarakat Untuk Mendukung Program Asimilasi Dan Integrasi Bagi Narapidana Anak Pada Masa Pandemi Covid-19. Res Judicata, 3(1), 51-65.

Scott, Jason Bartholomew. (2020). A pandemic in prisons. Social Anthropology, 28(2), 352-353. https://doi.org/10.1111/1469-8676.12857

Setiadi, Wicipto, Satino, Surahmad (2018). Sosialisasi Hukum Perlindungan Anak Dilingkungan Karang Taruna RT. 07 RW.14 Kelurahan Bahagia Kecamatan Babelan Kab. Bekasi. Jurnal UPNVJ.

Simpson, Paul L., \& Butler, Tony G. (2020). Covid-19, prison crowding, and release policies. The BMJ, 369(April), 1-2. https://doi.org/10.1136/bmj.m1551

Sulhin, Iqrak. (2020). Covid-19, Pemenjaraan Berlebihan, Dan Potensi Katastrofe Kemanusiaan. Jurnal Hukum \& Pembangunan, 50(2), 400. https://doi.org/10.21143/jhp.vol50.no2.2588

Tirtakusuma, Andreas Eno. (2020). Modifikasi Pelaksanaan Putusan Pengadilan (Kajian Pengeluaran dan Pembebasan Narapidana dan Anak Melalui Asimilasi dan Integrasi dalam Rangka Pencegahan dan Penanggulangan Penyebaran Covid-19). Selisik, $6(1), 15-29$.

Trisapto Wahyudi Agung Nugroho (2019). Analisa Kebutuhan Pembimbing Kemasyarakatan Balai Pemasyarakatan (Bapas) Bandung. Jurnal Ilmiah Kebijakan Hukum, Vol. 13 No. 1 Maret 2019.

Trisnawati, Niyan Ati. (2020). Pemberian Asimilasi dan Integrasi terhadap Narapidana dan Anak dalam Rangka Pencegahan dan Penanggulangan Penyebaran COVID-19 (Studi di Lembaga Pemasyarakatan Perempuan Kelas IIA Malang). Dinamika, 26, 1765-1774.

Umronah, Enny. (2020). Analisis Yuridis Pengawasan Asimilasi dan Integrasi bagi Narapidana dan Anak Ketika Pandemi COVID-19 (Studi di Balai Pemasyarakatan Kelas I Malang). Legal Spirit, 4(1). https://doi.org/10.31328/ls.v4i1.1554 